\title{
Commercialization channels of organic products in Brazil: analysis at the first level of the production chain
}

\section{Canais de distribuição de produtos orgânicos no Brasil: análise no primeiro nível da cadeia produtiva}

\author{
Andréa Rossi Scalco ${ }^{1}$ \\ Giuliana Aparecida Santini Pigatto \\ Roberta Souza ${ }^{2}$
}

\begin{abstract}
Specialized literature on organic production highlights the presence and concentration of retail, especially supermarkets, in the organic enhancement chain. This presents enormous obstacles for the entrance of small farmers in the production of organic products due to administrative barriers, in addition to pressure for lower prices by the supermarket retail network. This paper investigates the commercialization channels of organic production in Brazil. The survey was undertaken in 2013; questionnaires were sent to 900 out of approximately 11.200 farmers producing organic products; 216 answers were received. Analysis showed that approximately $90 \%$ of farmers provided for the internal market and $60 \%$ of the products were fresh fruits and vegetables. The distribution of organic products in Brazil is highly fragmented at the local, regional and national levels. The presence of supermarkets and intermediaries in the commercialization of fruits and vegetables is relevant, regardless of the size of the farm. There is a great dispersion of channels in the case of small farmers, although supermarkets rank second. However, direct commercialization (farmers markets) is the main form of commercialization of the produce. Commercialization triggered by social programs has guaranteed a considerable part of the income on small production units or small farms. It seems that high involvement of retail networks and agents in the agribusiness segment causes low development rates in small agricultural units and in local development due to the latter's low profit margins.
\end{abstract}

Keywords: Commercialization channels; Organic farmers; Organic products.

Resumo: A literatura sobre a produção orgânica vem destacando a presença e a concentração do setor de varejo, em especial o supermercadista, nas cadeias de valor de produtos orgânicos. Este fato é um grande obstáculo para a entrada dos pequenos agricultores na produção orgânica, haja vista as barreiras gerenciais desses agricultores, além da pressão por preços menores exercida pelas redes de varejo supermercadistas. Assim, o objetivo deste trabalho foi investigar os canais de comercialização de produção orgânica utilizados no Brasil. Foi realizado um survey com o envio de questionários a 900 agricultores orgânicos no Brasil (ano 2013), em um universo de cerca de 11.200 operações (agricultores), sendo que 216 questionários foram respondidos. Neste estudo, os resultados evidenciaram que cerca de $90 \%$ dos agricultores produzem para o mercado interno e $60 \%$ do que é produzido são frutas e vegetais frescos orgânicos. A extensão da distribuição do produto no Brasil é pulverizada, ou seja, em nivel local, regional e nacional. Em geral, é relevante a presença de supermercados e intermediários na comercialização de frutas e vegetais frescos, independentemente do tamanho da propriedade, seja esta pequena ou de grande porte. Em pequenas propriedades, há uma maior dispersão de canais, ressaltando-se que supermercados são o segundo canal mais importante e a comercialização direta -feiras de rua -é a mais importante forma de comercializar o produto. No entanto, em pequenas propriedades agrícolas a comercialização por meio de programas sociais tem sido um canal que garante uma parte considerável da renda em pequenas unidades de produção. Há indicações de que quanto maior o envolvimento de grandes redes de varejo e indústrias do agronegócio nesse segmento, em menor medida a pequena agricultura e o desenvolvimento local serão beneficiados.

Palavras-chave: Canais de comercialização; Propriedades orgânicas; Produtos orgânicos.

\footnotetext{
${ }^{1}$ Programa de Pós-graduação em Agronegócio e Desenvolvimento, Centro de Pesquisa em Administração e Agronegócio CEPEAGRO, Universidade Estadual Paulista - UNESP, Avenida Domingos da Costa Lopes, 780, CEP 17602-496, Tupã, SP, Brazil, e-mail: andrea@tupa.unesp.br; giuliana@tupa.unesp.br

${ }^{2}$ Departamento de Engenharia de Produção, Escola Politécnica, Universidade de São Paulo - USP, Almeida Prado, Travessa 2, 128, Cidade Universitária, CEP 05508-070, São Paulo, SP, Brazil, e-mail: robertacsouza@usp.br
}

Received Apr. 6, 2015 - Accepted Sept. 14, 2015

Financial support: CNPq (issue process n. 470976/2011-0). 


\section{Introduction}

According to the 2012 survey data on certified organic agriculture world-wide (IFOAM, 2012), organic agriculture has increasingly expanded worldwide, with approximately 37.5 million hectares cultivated by 1.9 million farmers in 164 different countries. When compared to 2008 , a $7.1 \%$ growth rate in cultivated area was observed, with a $35.7 \%$ increase in the number of farmers worldwide (IFOAM, 2010, 2014).

In 2012, the countries of the Pacific controlled $33 \%$ of the area with organic products, followed by Europe (30\%) and Latin America (18\%). Australia has the largest land extension in organic products, with 12 million hectares, followed by Argentina, with 3.6 million, and the US with 2.2 million (Data from the report for the year 2012) (IFOAM, 2014). World sales of organic products in 2012 reached 64 billion dollars, a $25.6 \%$ increase on 2008 (IFOAM, 2010, 2014).

In terms of consumption, North America and Europe are the main consumers of this booming market, representing approximately $95 \%$ of demand in 2012 . Latin America, especially Argentina, Peru, Chile and Colombia, are the main exporters of primary organic products to these regions, while Brazil is the biggest market of organic food and beverages in Latin America (IFOAM, 2014).

Brazil is one of the main countries in the world with the largest area for organic crops, featuring 705,000 hectares in 2012 , ranking $11^{\text {th }}$ worldwide and $3^{\text {rd }}$ in cultivated area in Latin America, followed by Argentina and Uruguay, with 12,526 producers (IFOAM, 2014). Most production areas are small and family-run, mostly located in the south and southeastern regions of the country. According to the Brazilian Ministry of Agriculture, Livestock and Food Supply (Brasil, 2010), 80\% of Brazilian produce is for exports, especially to the European Community.

International literature on organic products tends to equal organic agriculture to conventional agricultural products, from delivery to middlemen to big retail networks. However, organic agriculture has a traditional importance for small farmers and producers since it favors their entry into global market and increases their income from their products (Blanc, 2009; González \& Nigh, 2005; Vorley \& Fox, 2014; Elder et al., 2014). According to IFOAM (2010), small and medium-sized producers are responsible for $95 \%$ of organic production.

The increase of corporative players in the agribusiness sector and the concentration of retail market are a counterpoint to the principles of organic agriculture. However, there are few studies on the organic food sector in Brazil (Blanc \& Kledal, 2012) and those based on quantitative research and distribution channels are scarce. Previous research about Brazil indicates that the biggest supermarket chains offer their own trademark in organic products. According to Guivant (2003), According to Guivant (2003), by selling organic products to great retailers through brokers, the producers of organic products only receive $14 \%$ of the final value of the product, in contrast to approximately $31 \%$ to intermediaries and $55 \%$ to supermarkets.

Current paper investigates the commercialization channels for organic products in Brazil and verifies whether the presence and concentration of retail supermarket chains, highlighted in international literature, also valorizes organic food in Brazil.

Current paper is subdivided into six parts. The second and third parts describe the Brazilian market of organic products and their commercialization channels. The fourth part deals with the methods employed, while the fifth part discusses results of survey. The sixth part forwards the final considerations on the issue.

\section{The history of the production of organic products in Brazil}

Total area in Brazil with organic production certification amounts to one million hectares (IFOAM, 2014), with the states of Mato Grosso, Pará and Amapá as the leading representatives. The state of Pará has the highest number of producers, totaling 3,300, with all types of organic certification; followed by the states of Rio Grande do Sul, with 1,200; Piauí, with 768; São Paulo, with 741, and Mato Grosso, with 691 (Organicos, 2012). The northern region of Brazil has the most extensive area with organic agriculture, totaling 778,800 hectares and 3,800 production units, followed by the center-western region with 650,900 hectares and 1,100 production units (Organicos, 2012).

Between 2006 and 2010, Brazil exported several in natura organic products (such as mango, coffee, corn, papaya, avocado) and semi-processed or processed products (such as soybean, sugar, soy meal, wastes from soy oil extraction, powder cocoa and ground coffee). The most representative products in terms of production rates were ground soybeans $(29.25 \%)$, wastes from soy oil extraction (19.8\%) and sugar and saccharin $(14.27 \%)$. In terms of volume, the same exported products may be mentioned, although oil residues came third. In other words, soybean exports predominated with $28.27 \%$; sugar-saccharin featured $21.81 \%$ and wastes from soy oil extraction with 20.15\% (Brasil, 2010).

Further, since demands by the internal market for organic products are on the increase, producers are directing their attention to this important demand. The organic products market in Brazil in 2012 reached a total of 750 million dollars, with an estimated 1 billion for 2014 (IFOAM, 2014). Fresh products, for example, are mostly restricted 
to the internal market since their quality does not meet exports standards (Buainain \& Batalha, 2007).

Although the 2003 regulation (Brazilian Federal Law n. 10,831 (Brasil, 2003), published on 23/12/2003, dealing with production and commercialization procedures for organic products in the country) and the 2007 decree (Decree n. 6.323, published on 27/12/2007 (Brasil, 2007), on the activities of organic agriculture regulated by Brazilian Federal Law n. 10,823 published on 23/12/2003 for the internal market may, at first sight, turn out to be an impediment to small farmers, on the other hand, markets may be expanded, including exportation, as laws are established and consolidated.

Brazilian law establishes three instruments to certificate of organic products: the the Third Party Organization, the Participatory Guarantee Systems and Social Control for direct sale without certification. Certification by audit (third party) is the process in which a third party - which does not have link with who will be certified - ensures that a product, process or service meets certain requirements, by issuing a certificate. There are two ways of certification, individually or in groups. A second control mechanism is the Participatory Guarantee System (PGS) of organic quality. This system is characterized by collective responsibility of theirs members in obtaining this control mechanism, but it is noteworthy that the GSP must have a Participatory Body Conformity Assessment (PBCA), legally constituted (being a legal entity) and accredited in MAPA. The third option for control is social control in direct selling. This certification mechanism offers the producer a certificate that the product it is marketing is organic, but the producer can not use the organic label (Scalco \& Servi, 2014).

Certification has an important role in the purchasing-selling relationship since food quality and safety cannot always be assessed in a direct way. In fact, certification reduces uncertainties with regard to the product's quality by providing information on the product and on the production process (Machado, 2000). In the specific case of in natura organic products, certification guarantees to intermediaries and consumers that the product is actually organic (free from pesticides), that the products do not harm the environment, and that slave labor or equivalent is not employed in its production. On the other hand, certification does not guarantee such characteristics as form, texture, taste, aspect, in other words, characteristics perceived by the consumer. Needless to say, the absence in these features may affect the buying decision.

Although certification is an efficient mechanism to reduce asymmetry of information for the client and consumer, especially for certain attributes of the product, it fails to guarantee other aspects of agreement between the seller and the buyer. In other words, regularity in transactions, conditions of commercialization (price, deadlines, payment) and access to other markets are not warranted.

Further, in Brazil, the organic products segment has to cope with obstructions in production, commercialization and institutionalization, all of which should be overcome. Access to markets and premiums on prices, frequently uncertain, even on foreign markets, should be underscored (Fonseca et al., 2009). Small producers have enormous difficulties to access big markets (supermarkets and shops specialized in natural products), while retail networks prefer commercialization deals involving fresh organic products with big producers due to lower transaction costs and more competitive prices.

\section{Commercialization channels}

According to Araújo (2003) and Rosa et al. (2009), commercialization channels are a set of interdependent firms that deploy the flow of products or information within an agreed form and constitute a structure of internal and external organizational units.

Distribution channels attend demand of products, or rather, they provide and warrant availability of the products, quality and price which meets the requirements of the final consumer. They may also guarantee market issues such as decrease in delivery time and freight costs (Bucklin, 1966 apud Stern et al., 1996).

Each different flow between agents in distribution channels has a specific aim. Chart 1 lists these flows described by Neves (1999).

Neves (1999) describes the role of each flow and underscores that all flow should be executed and monitored, as follows:

- Physical flow of products: implies the logistic for the distribution of the product;

- Exchange of property rights: refers to property rights of the product;

Chart 1. Flows in distribution channels.

\begin{tabular}{|c|l|}
\hline Direction of flow & \multicolumn{1}{c|}{ Flows } \\
\hline Products $\longrightarrow$ Consumer & $\begin{array}{l}\text { Physical flow of products/ } \\
\text { services (logistic) } \\
\text { Exchange of property rights } \\
\text { Flow of communication } \\
\text { (enhancement) }\end{array}$ \\
\hline Products $\longrightarrow$ Consumer & $\begin{array}{l}\text { Flow of information } \\
\text { Flow of payment } \\
\text { Flow of demands }\end{array}$ \\
\hline Products $\longrightarrow$ Consumer & $\begin{array}{l}\text { Negotiations } \\
\text { Financial flow (loanings) } \\
\text { Risks }\end{array}$ \\
\hline
\end{tabular}

Source: Neves (1999). 


\section{- Flow of communications (enhancement):}

its function establishes demand on the product/service, since the participants of the channel are accountable for the contacts;

- Flow of information: implies communication between agents, mainly on the perception of the product on the consumers;

- Flow of payment: flow of payments among the agents;

- Negotiations: they exist in all stages of the chain (negotiations on the type of product, pay installments, volume, packing and others).

According to Rosenbloom (2002), the channel strategy must be elaborated prior to logistic management since it involves a series of flows, such as product flow (the physical transportation of the products), negotiation flow (interaction of buying and selling associated to transfer of products), property flow (rights on products in so far as they are transacted), information flow (throughout the entire production chain) and promotional flow (advertisements, sales).

The amount of levels in a distribution channel consists of the different arrangements in the distribution channels. The number of intermediate levels between production and the consumer defines the extension of the distribution channels, which may be short or long. Short or long extensions of the distribution channels are required to attend to the efficiency of the process, specialization and division of labor, increase of contractual efficiency for reduction of transaction costs, and the facility in the process to find suppliers and clients (Stern et al., 1996; Rosenbloom, 1999).

Channels are variables specific to each type of product and region. They involve several commercial agents, such as agroindustry, logistics and others. According to Araújo (2003), the distribution channel may be subdivided into eight levels, namely, a) agricultural producers; b) intermediaries (people or firms); c) agro-industries, local and concentrated supply centers (large scale intermediaries); d) representatives, distributors and sellers; e) wholesalers, regional supply centers, goods exchange market, government, internet, and others, or rather, channels that brings closer the consumer and the product; f) segments for international commerce and those that make direct contact with consumers, ranging between exportation and fairs, supermarkets and outlets; g) consumers; h) imports segment.

According to Neves (1999), the distribution channel includes manufacturers, intermediaries and consumers as the main participants. It should be underscored that that 'facilitators' act close to the channel members. They are agents that give support to participants in such services as market survey, transport, insurance, advertisement, deposits, financial institutions, consulters and certification firms. Facilitators and participants differ since the former do not have property rights on the product negotiated in the channel. Since distribution channels may have different levels, depending on the product, and this fact may imply different wholesale levels. In fact, it directly depends on the service levels aggregated to the product. According to Neves (1999), the highest the service degree added to the product, the greater is the number of intermediaries. It should also be emphasized that empathy must exist between the members of a channel so that the product or service would satisfy the consumer.

Current research takes into account the first level agent, or rather, the rural producer. Producers of organic products are numerous and predominantly small. They supply their products at all levels of commercialization, even though they frequently concentrate on a single level, depending on the place, product or season of the year (Araújo, 2003). In some cases, many producers undertake, even partially, the commercialization of their produce. In associations or cooperatives, they endeavor to be technically and economically efficient to increase their bargain power on the markets (Barros, 2007).

According to Pigatto \& Alcântara (2006), changes in the behavior of the final consumer and in the strategies of the agents close to consumers force them to undertake important changes in the structure of distribution channels in terms of limits and forms of activity. Although there are common interests and conflicts within the distributor-supplier relationship, they agree to be partners to make goods available for the final consumer and to maintain a clear-cut negotiation between the two parts. In their analysis on distribution channels of agricultural inputs, Castro et al. (2007) pointed out that a greater possibility of conflicts exists when a long channel is involved. According to the authors, the division of tasks and profits in a distribution network requires synchronized and integrated work by all partners, even though imbalance of power and opportunistic activity of both parts always lurk behind.

\subsection{Commercialization channels for organic agriculture}

According to Blanc (2009), the sector of organic products may have a better distribution of forces and power among the agents involved in the production and distribution channels since it benefits from farmers' innovation processes seen in their new relationships with consumers and favoring the emancipation of the whole system (Blanc, 2009). This perspective may be perceived also from experiences in European countries with its growing network of alternative food. 
One example is the "Gruppi di Acquisto Solidare" (GAS), with more than 120 solidary purchasing groups in Tuscany, Italy, formed by consumers who collectively and directly purchase from producers (Rossi \& Brunori, 2010).

However, innovation in the relationship with consumers cannot be understood in all thes system of organic production (an alternative food system, affected by social movements and experiences, and a commercial food system, led by the expansion of supermarket chains), since they are formed by productive agents of different sizes and structures, with different delivery methods for their products.

The greater the involvement of the great retail networks and agribusiness agents in the segment, the less are the assets that small farmers and local development receive. For instance, in Brazil, the organic products segment has been impaired by big financial agents, evidenced by the development of long supply chains. By the end of the 1990s, the export segment and the retail segment (for the internal market) became robust in the wake of the previously dominant shorter supply chains (Guivant, 2003).

As part of a social construction project, the organic products movement in Brazil in the 1980s started alternatives to support small-scale agriculture. The movement was enhanced by the direct contact between producers and consumers through the market system of farmers and direct commercialization, organized by NGOs, associations and religious movements.

However, henceforth and under the pressure of producers' organizations and companies attracted by the economic opportunities linked to the sector (processing, exports), the Brazilian government started establishing regulations for the segment of organic products to enhance the development of small-sized agriculture (Blanc, 2009).

The organic products segments that developed fast were the export-oriented firms and retail supermarkets (for the internal market). Within the context of a highly competitive and globalized market, the development of long distribution channels exceeded the short channel ones. In recent years, the concentration of supermarkets in Brazil has been acknowledged as a motile force for the internal market of organic products. In fact, at present, practically all big companies sell organic fruits and vegetables (Schultz, 2006; Blanc, 2009).

According to Schultz (2006), different commercialization channels exist for organic products, comprising fruits and vegetables fairs, basket delivery, specialized shops, supermarkets, exports, agroindustry and the institutional market (government-bought organic products). Even intermediary companies are responsible for the segment's logistics as a link between producers and big retailers. They are groups based on cooperatives formed by farmers to aggregate value to the organic product and access the big retail networks. The Horta e Arte (Kitchen Garden and Art) is an association of small producers with 135 agricultural suppliers and 120 employees for the delivery of the products (Martins et al., 2006).

Big retail companies consign high profit rates on organic products with very low risks, since in most cases the costs of non-sold products is the producer's liability. Supermarkets still depend on suppliers. Since demand is higher than supply, the possibility that supermarkets apply a greater pressure on producers in the coming years is very great (Carvalho, 2005; Blanc, 2009). Carvalho (2005) assessed the agriculture of the state of São Paulo, Brazil, and reported that the high prices demanded by supermarkets make organic products a privilege of people with high buying power. In public fairs, prices may be half those at supermarkets. However, according to the author, difference in price when compared to that of the conventional product is the great stimulus for the entry of new producers.

In their studies on actions to develop the organic market in São Paulo and in their evaluation together with researchers and industry management, Souza et al. (2013) have also found that high prices of organic products in supermarkets make viable purchase only by 'rich people'. They also reveal changes related to social structure, such as the need for cooperatives among production agents, strengthening of local associations of producers and consumers, and to public actions, such as the strengthening of fairs and new market outlets.

Current paper investigates distribution channels for organic products in Brazil. Besides, some variables for analyzing the channels, such as farm size, types of products, processing level, place and type of organic certification are also taken into account. The distribution channels commonly used in Brazil are characterized. Chart 2 presents a descriptive synthesis of the channels.

\section{Research methodology}

Current study is supported by a descriptive research which investigates the characteristics of certain populations or phenomena or establishes relationships between variables (Gil, 2002). It provides the researcher with a better understanding of the behavior of several factors that affect a determined phenomenon (Oliveira, 2001). Prior to descriptive research, a review of the literature was undertaken on the theme of organic production (characteristics) and commercialization channels retrieved from Brazilian and international electronic scientific data bases for theoretical subsidies in research analysis.

The survey method was used for field research and data were collected from Brazilian organizations related to the production of organic products, such as 
Chart 2. Distribution channels for producers of organic products.

\begin{tabular}{|c|c|}
\hline $\begin{array}{l}\text { Distribution channels } \\
\text { for producers of organic } \\
\text { products }\end{array}$ & Definition \\
\hline One's own consumption & $\begin{array}{l}\text { Consumption by the family of the producers of the product produced on their own } \\
\text { farm. }\end{array}$ \\
\hline Public fairs & $\begin{array}{l}\text { In Brazil, public fairs are usually weekly retail markets in the open air, organized } \\
\text { as a municipal service for the distribution of food and basic food products. Mobile } \\
\text { retail equipment, with temporary installations on the streets, commercializes fruits, } \\
\text { legumes, vegetables, fish, snacks and artisan products. }\end{array}$ \\
\hline $\begin{array}{l}\text { Ecological } \\
\text { (organic products) fairs }\end{array}$ & $\begin{array}{l}\text { Similar to public fairs, ecological or organic products fair are generally } \\
\text { conducted on streets or squares. The difference is that the fair is exclusively for } \\
\text { agro-ecological products. }\end{array}$ \\
\hline Home delivery & $\begin{array}{l}\text { It is a direct selling strategy to consumers who demand the products directly from } \\
\text { the producers. It is a basket of green groceries and fruits which may be delivered at } \\
\text { the consumers' home or retrieved from the farm. }\end{array}$ \\
\hline Intermediaries & $\begin{array}{l}\text { Intermediaries are companies whose business is the distribution and/or } \\
\text { commercialization of organic products. There are several types of levels: } \\
\text { intermediary people or firms; agro-industrial, local and concentrated supply } \\
\text { centers; representatives, distributors and sellers or even associations. They are } \\
\text { chain agents without any direct contact with the consumer. }\end{array}$ \\
\hline Specific groceries & $\begin{array}{l}\text { Groceries which sell different products such as functional and agro-ecological } \\
\text { products. They are frequented by more aware consumers who are generally prone } \\
\text { to pay higher prices for healthier products. }\end{array}$ \\
\hline Food acquisition program & $\begin{array}{l}\text { It is a public acquisition system within the Brazilian government program Fome } \\
\text { Zero. Although not specific to organic products, it is an opportunity for producers } \\
\text { since it offers a } 30 \% \text { premium above reference prices of local or regional market. }\end{array}$ \\
\hline $\begin{array}{l}\text { Supermarkets and } \\
\text { hypermarkets }\end{array}$ & $\begin{array}{l}\text { The main representative of self-service establishments, characterized by the } \\
\text { selection of products by the consumer who takes them to the teller outlet, pays for } \\
\text { the products without the intermediation of the teller. The supermarket is different } \\
\text { from the hypermarket in size, number of items, sections, number of check-outs and } \\
\text { billing amount. }\end{array}$ \\
\hline
\end{tabular}

Source: Elaborated by the authors based on Mascarenhas \& Dolzani (2008); Barros et al. (2007 apud Silva et al., 2003); Blanc \& Kledal (2012); ABRAS (2010); Araújo (2003) and Schultz (2006).

the Association of Producers of Organic Products and Certified Companies of Organic Products. The guidelines for this empirical method are based on Forza (2002). The MAPA controls the commercialization of organic products in Brazil and it is responsible for acknowledging and authorizing certified companies. When the data base for current research was elaborated in 2012, there were 11 companies authorized by MAPA.

There are two ways to certificate organic production. One of them is by Participatory Guarantee System. The Association of Natural Agriculture of Campinas and Region (ANC); Association Ecovida of Participative Certification (Ecovida Network), Association of Biological Farmers of the state of Rio de Janeiro (ABIO) and the Brazilian Association of Biodynamic Agriculture (ABD) were the companies authorized to issue the organic certificate.

The other system of certification could be issued by a Third Party Organization. The following companies were authorized to issue the organic certificate: Instituto de Tecnologia do Paraná (TECPAR), Ecocert Brasil Certificadora Ltda, IBD certificações Ltda, IMO Control do Brasil Ltda, Agricontrol Ltda (OIA do
Brasil), Instituto Nacional de Tecnologia (INT) and Instituto Chão Vivo de Avaliação da Conformidade. Data on three (Agricontrol Ltda, Associação dos Agricultores Biológicos do Estado do Rio de Janeiro (ABIO) and the Instituto Chão Vivo de Avaliação da Conformidade) out of the 11 organizations could not be obtained. The first two refused to participate in the research and the e-mail addresses and telephones listed by MAPA were incorrect. Some firms accepted contact with producers, while in the case of others data could only be retrieved from their electronic sites.

Since no data base (product, address, type of certification) was available on the MAPA site at the start of the survey (2012), a search through the sites of associations, certifying companies, cooperatives and distributors was performed to develop a data base of producers in Brazil.

Questionnaires with closed questions were later sent to nine hundred producers of organic products. The issues comprised activity and property (types of products, size of areas, types of certification) and marketing channels (factors found in Table 1, particularly the physical flow of products, compared to other types 
of flow functions). The questionnaires were sent by e-mail and ordinary mail. Interviews are made by phone and face-to-face. Two hundred and sixteen $(23.88 \%)$ answers were received, whilst sampling was randomized according to the data bank generated during research.

Margin of error amounted to $7.5 \%$ within a total of 11,524 establishments of organic products (listed on the MAPA site after data collection in 2012). According to the samples, research was performed in 2012 and 2013 for the states of Bahia, Ceará, Mato Grosso, Mato Grosso do Sul, Minas Gerais, Paraná, Paraíba, Pará, Pernambuco, Piauí, Rio de Janeiro, Rio Grande do Sul, Rondônia, Santa Catarina and São Paulo. It should be underscored that the most producers in the sample hailed from the states of São Paulo (24.88\%), Rio Grande do Sul (14.08\%), Santa Catarina (11.27\%), Goiás (10.80\%), Paraná (9.39\%) and Minas Gerais (8.92\%). Further, $61 \%$ of the answered questionnaires came from fruit and vegetable (FLV) producers. Data were analyzed by statistical descriptive tools (descriptive measurements, dynamics tables and graphs) and data of the producer segment were crossed with the those of marketing channels employed.

\section{Results and discussion}

The distribution channels within the commercialization process were evaluated to appreciate the interdependent organizations that cause the flow of products or information on agricultural production. The commercialization channels by which rural producers deliver their products (the analysis was undertaken with regard to the type of processing, farm size and type of certificate) were analyzed. The participation of retail networks within the chain of the value of organic products was also assessed. Other important characteristics, such as type of commercialized product, processed form, market amplitude (local, regional, national and international) were also evaluated.

\subsection{Types of products}

Analyses showed that fruits and vegetables, with shorter durability and shelf life when compared to legumes, amounted to $60.6 \%$, or 34.4 and $26.2 \%$ of the products, respectively. The results about types of products are corroborated by Buainain \& Batalha (2007) who reported that fresh products were mainly directed to the internal market. Processing changes in the products were also analyzed. They comprised washing, packing, semi-processing (cuts, minced, dried, dehydrated), processing (preparation of jellies, juices and others) or no changes whatsoever. Packed (average $43.5 \%$ of all products) and washed (23.7\%) products were the most important. Due to their short durability, fruits and legumes may receive more processing, as Figure 1 shows.

Table 1. Commercialization channels used for each type of processing.

\begin{tabular}{cccccccccccccc}
\hline \multicolumn{10}{c}{ Channels/ Type of processing (\%) } \\
\hline \multicolumn{1}{c}{ Washed } & \multicolumn{1}{c}{ Packed } & \multicolumn{3}{c}{ Semi-processed } & \multicolumn{1}{c}{ Processed } & \multicolumn{1}{c}{ Did not answer } & Any alterations \\
\hline Public fairs & 19.8 & Interm. & 17.9 & $\begin{array}{l}\text { Specific } \\
\text { groceries }\end{array}$ & 28.4 & $\begin{array}{c}\text { Specific } \\
\text { groceries }\end{array}$ & 20.9 & Superm.. & 16.7 & Interm. & 62.5 \\
Superm. & 17.1 & $\begin{array}{c}\text { Specific } \\
\text { groceries }\end{array}$ & 14.3 & Interm. & 19.4 & Superm.. & 14.9 & $\begin{array}{c}\text { Specific } \\
\text { groceries }\end{array}$ & 16.7 & $\begin{array}{c}\text { Public } \\
\text { fairs }\end{array}$ & 12.5 \\
$\begin{array}{c}\text { One's own } \\
\text { consumption }\end{array}$ & 15.3 & Superm. & 13.9 & PAA & 13.4 & Interm. & 14.9 & Interm. & 16.7 & Superm. & 8.3 \\
Subtotal & 52.3 & Subtotal & 46.2 & Subtotal & 61.2 & Subtotal & 50.7 & Subtotal & 50.0 & Subtotal & 83.3 \\
Others & 47.7 & Others & 53.8 & Others & 38.8 & Others & 49.3 & Others & 50.0 & Others & 16.7 \\
Total & 100.0 & Total & 100.0 & Total & 100.0 & Total & 100.0 & Total & 100.0 & Total & 100.0 \\
\hline
\end{tabular}

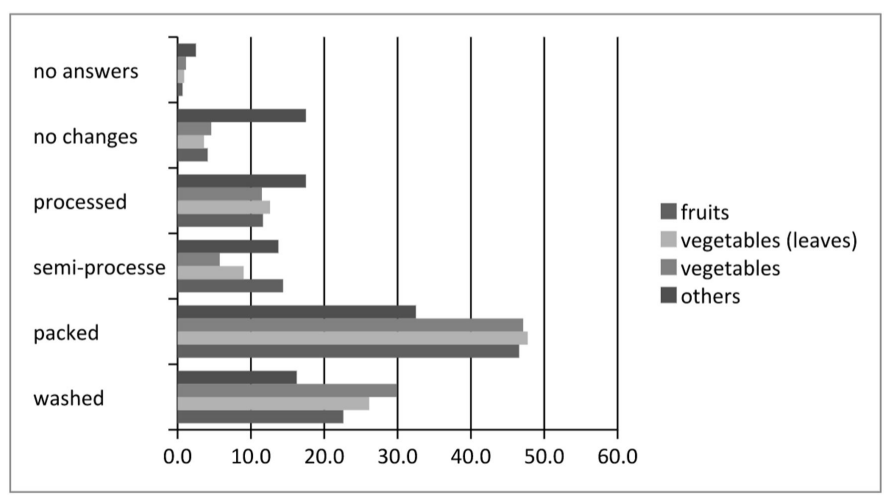

Figure 1. Type of improvement for each category of products (\%). 
The category of other products, such as coffee and milk, should be highlighted since they have a high participation rate $(17.5 \%)$ in the category of processed goods, with no changes.

The place of origin of the products' production/ transformation was also assessed, with the following distribution (in decreasing order of representativeness, processing/ state):

I. Packed products mainly originated from the states of São Paulo, Santa Catarina and Paraná (62\% in the package category);

II. Washed products, mainly originated from the states of Goiás, São Paulo and Rio Grande do Sul (75\% in the washing category);

III.Semi-processed products originated mainly from the states of Pará, Rio Grande do Sul, Santa Catarina and São Paulo (with $80,6 \%$ in the category of semi-processed products);

IV.Processed products from the states of São Paulo, Rio Grande do Sul and Minas Gerais (totaling $50.9 \%$ of processed category);

V. Products without any transformation, originating from the states of São Paulo and Mato Grosso do Sul (totaling $80 \%$ of this category).

The above set of data demonstrates the importance of the states of Rio Grande do Sul, Santa Catarina and São Paulo as the biggest producers of organic products in Brazil since they were relevant (\%) in the five processing categories of the evaluated products. The following points must be underscored: the importance of the state of Goiás for the washing of organic products $(6.7 \%$ of total); the importance of the state of São Paulo for packed organic products (12.9\% of total); the importance of the state of Pará for semi-processed organic products $(5.7 \%$ of total) and of the state of Roraima for products without any transformation ( $4.31 \%$ of total).

\subsection{Commercial channels}

The distribution channels were evaluated to detect interdependent organizations that cause the flow of products or information of the products from agricultural produce. They were segmented into supermarket, specific shop, intermediary, Food Acquisition Program, public fair, ecological fair, home delivery, consumption by producer and others, as explained in 3.1.

Table 1 shows that a) the commercial channel Supermarket ranks among the three most important channels (answer percentage) for the categories Processing (washed, packed, processed, without any alteration and 'did not answer'); b) the distribution channel Intermediary is also present among the three most important ones for the category Processing (packed, semi-processed, processed, without any alterations and 'did not answer'); c) the higher the level of the product's processing, the greater the trend for its delivery through specialized channels, such as specific shops (higher percentage of delivery of semi-processed and processed types of products); d) low level of the product's processing is done through less specialized channels, such as public fairs (high percentage of delivery of washed products, $19.8 \%$, and "without any alterations", $12.5 \%$ ).

The importance of supermarkets is presented by Schultz (2006) who argue about the concentration of supermarkets for the sale of organic products to the internal market. In fact, practically all big firms currently sell organic products, especially fresh fruits and vegetables (Schultz, 2006).

\subsubsection{Relationship between commercialization channels and farm size}

The importance of the channels Supermarket and Intermediary may be linked to farm sizes, with special reference to $10-100$ ha farms and over (+300 ha). Big farms concentrate their distribution of products into three channels, namely, intermediary $(33.3 \%)$, specific shop (26.7\%) and supermarket (20\%).

There is an almost homogeneous distribution (between 11 and 17\%) among the channels employed in less than 10-ha-size farms. Similarly, in the case of big producers, the Intermediary and the Supermarket are among the main channels used, coupled to the specific shop. It should be underlined that, in the case of this agent, the public fair is one of the most relevant channels used for the distribution of organic products. This was not expected prior to the survey (Table 2).

Small producers in official government programs are very important. They are represented by the small farm with up to 10 ha. Distribution by institutional programs (important within the category of semi-processed products) aims at the acquisition of products from family agriculture by the government for the formation of government stocks or for donations to undernourished people (such as squatters, ex-slave communities, indigenous populations and others). The products are also distributed to public social programs (such as kindergartens, schools, community kitchens, low-budget restaurants and philanthropic societies (CONAB, 2006).

Alternative channels, such as public fairs, agro-ecological fairs and home delivery, are not commonly used by big producers (over 300 ha). Small producers up to 100 -ha-size farms do the job. 
Table 2. Commercialization channels used according to size of farm.

\begin{tabular}{|c|c|c|c|c|c|c|c|}
\hline \multicolumn{8}{|c|}{ Channels/ size of farm (\%) } \\
\hline \multicolumn{2}{|l|}{ Up to 10ha } & \multicolumn{2}{|c|}{ 10ha - 100ha } & \multicolumn{2}{|l|}{$100-300 \mathrm{ha}$} & \multicolumn{2}{|l|}{ Over 300ha } \\
\hline Public Fairs & 17.0 & Intermediaries & 24.8 & Specific groceries & 21.1 & Intermediaries & 33.3 \\
\hline Supermarkets & 13.7 & Specific groceries & 17.1 & Supermarkets & 18.4 & Specific groceries & 26.7 \\
\hline Intermediaries & 13.7 & Supermarkets & 13.8 & $\begin{array}{l}\text { One's own } \\
\text { consumption }\end{array}$ & 15.8 & Supermarkets & 20.0 \\
\hline Specific groceries & 12.9 & Public Fairs & 11.4 & Intermediaries & 13.2 & $\begin{array}{l}\text { One's own } \\
\text { consumption }\end{array}$ & 13.3 \\
\hline PAA & 11.6 & PAA & 9.0 & Home delivery & 13.2 & Others & 6.7 \\
\hline Ecological Fairs & 11.2 & Ecological Fairs & 7.6 & Ecological Fairs & 10.5 & PAA & 0.0 \\
\hline $\begin{array}{l}\text { One's own } \\
\text { consumption }\end{array}$ & 11.2 & $\begin{array}{l}\text { One's own } \\
\text { consumption }\end{array}$ & 7.1 & Public Fairs & 5.3 & Public Fairs & 0.0 \\
\hline Home delivery & 5.8 & Home delivery & 6.2 & Others & 2.6 & Ecological Fairs & 0.0 \\
\hline Others & 2.9 & Others & 2.9 & PAA & 0.0 & Home delivery & 0.0 \\
\hline Total & 100 & Total & 100 & Total & 100 & Total & 100 \\
\hline
\end{tabular}

Intermediaries are mainly used by small-sized producers. In fact, the Intermediary is used by one fourth of the producers with 10-100 ha and by one fifth of producers with up to $10 \mathrm{ha}$. The fact corroborates study by Blanc (2009) on the relevant insertion of producers in the great supermarket network, even though they use intermediate agents in commercialization due to their small bargain power and the lack of administration capacities for such transactions. The relevance of the intermediary in the commercialization of small producers of organic products is also due to the lack of time for commercial activities. Although it is not the best channel, it is the most convenient form for the small producer. The greater the involvement of big retail networks and agribusiness agents in this segment, the lower is the small-scale agriculture and local development benefitted, due to slight profit margins. For instance, during the last years, the sector of organic products has been jeopardized by agents with strong financial power. This fact may be evidenced by the development of long supply chains as current paper has shown.

Specific shops selling organic products are another relevant channel. Although widely used by all types of farm sizes, they are especially relevant for big-sized farms (>300 ha). The above fact goes contrary to secondary data since the predominance of bigger farms in more aggressive channels, such as supermarkets/hypermarkets was expected. In the case of big producers, the specific shop is preferred to the supermarket.

\subsubsection{Relationship between commercialization channels and types of certification}

Commercialization channels were also evaluated by the variable type of certification adopted by agents, which may be Certification of Third Party (individual or group) and Participatory Guarantee System. The above segmentation follows Blanc \& Kledal (2012) who report the existence of at least three production systems of organic products in Brazil. One is directed for the foreign market and two for the internal one. They are foregrounded on a) an alternative food system which uses a participative certification; b) a commercial market food system which uses a third party certification (individual or group).

Table 3 demonstrates that those that adopt the Certification of Third Party have three main commercialization channels (in decreasing order of participation): intermediary, specific shops and supermarkets; Participative Certification agents have the public fairs, ecology fairs and the Food Acquisition Program (PAA) as their main channels.

It may be inferred that the different agents who adopt the two systems of certification (third party and participative) also use more direct channels to the final consumer. Longer channels are practiced by the holders of Certification of Third Party. However, big producers, with third party certification, also use specific shops as an alternative for commercialization. In fact, results from current research indicate it as the second most important channel used by producers of the commercial system and holders of the Certification of Third Party (respectively, 17.1\% and 16.7\%).

\subsection{Place of distribution}

The places of distribution of organic products were evaluated to estimate participations in the internal (and its extension) and external market. Results demonstrate that production (90\%) largely goes to the internal market and only $10 \%$ to the foreign one. Delivery to the internal market occurs (in decreasing participation of answers) within the municipality of the producer $(26.4 \%)$, in the country 
as a whole $(24 \%)$, in the state of the producer $(21 \%)$ and region (18.6\%), as Figure 2 shows.

In fact, producers may employ a combination of areas for the sale of their products due to the size, place level of information and access (or not) of more extensive distribution channels. For instance, in sales for the external market, it is a more recurring strategy for those who already put their wares for sale in the country as a whole. As a general rule, Table 4 demonstrates that sales at short distances (within the producer's municipality) occur for low price products, such as washed and packed organic products, whereas semi-processed and processed products are sold in more distant places. Coffee produced in the state of Pará and sold without any transformation may be the only exception. However, Pará coffee has physical characteristics proper for export that make it endure longer distances and longer shelf life than FLV products. Table 4 shows the main selling places of organic products (in decreasing order of importance) for each type of processing.

Although the rate of sales for the external market is low (10\%), it makes the country one of the major producers within Latin America, together with Argentina and Uruguay. However, the samples, which concentrated on FLV, do not represent the main Brazilian exports. The sample was not representative for sugar and soybean which are major export organic products.

Figure 3 shows that the main importing countries are the European Union (56.9\%), with a significant demand by Germany (25.4\% of all countries) and Switzerland (19.6\% of all countries), the US (11.8\%) and Japan (7.8\%). Data corroborate report by Willer \& Kilcher (2011) placing the US and the European Union countries as the main world importers of organic products.

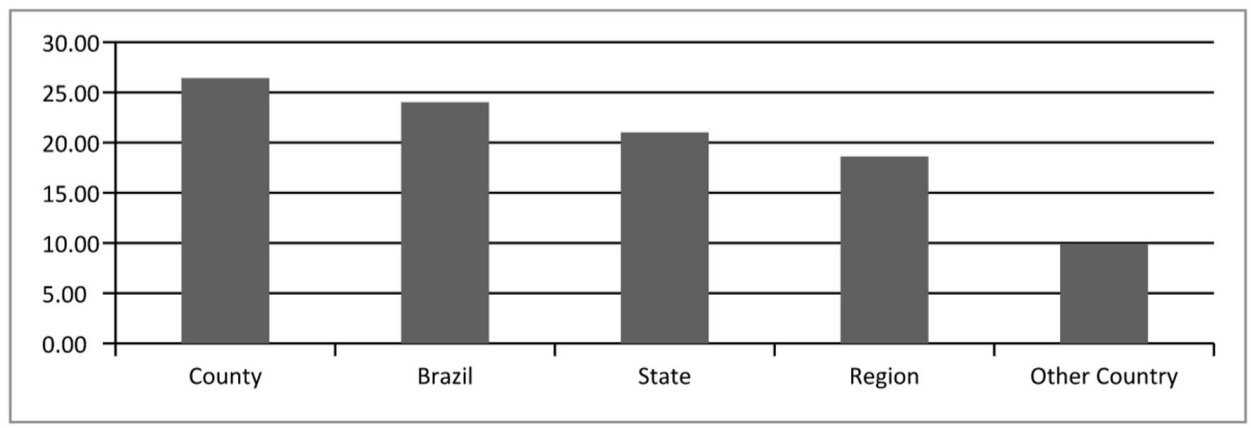

Figure 2. Delivery areas of organic products.

Table 3. Commercialization channels by types of certification.

\begin{tabular}{lccc}
\hline $\begin{array}{c}\text { Channels/ types of } \\
\text { certification (e\%) }\end{array}$ & $\begin{array}{c}\text { Cert. of third party } \\
\text { (individual) }\end{array}$ & $\begin{array}{c}\text { Cert. of third party } \\
\text { (group) }\end{array}$ & $\begin{array}{c}\text { Participatory Guarantee } \\
\text { System }\end{array}$ \\
\hline Supermarkets & 16.3 & 16.0 & 7.5 \\
Specific groceries & 17.1 & 16.7 & 11.2 \\
Intermediaries & 20.8 & 21.2 & 10.3 \\
PAA & 8.3 & 8.3 & 13.1 \\
Public Fairs & 9.2 & 15.4 & 19.6 \\
Ecological Fairs & 8.3 & 5.1 & 17.8 \\
Home Delivery & 7.5 & 3.8 & 7.5 \\
One's own consumption & 8.3 & 12.2 & 10.3 \\
Others & 4.2 & 1.3 & 2.8 \\
Total & 100 & 100 & 100 \\
\hline
\end{tabular}

Table 4. Main selling places of products for each type of processing of the product.

\begin{tabular}{ccccc}
\hline Washed products & Packed products & Semi-processed products & Processed products & Any alterations \\
\hline County & County & $\begin{array}{c}\text { State, Brazil and other } \\
\text { country }\end{array}$ & Brazil & $\begin{array}{c}\text { Brazil and other } \\
\text { country }\end{array}$ \\
$\begin{array}{c}\text { County, state and } \\
\text { Brazil }\end{array}$ & Region & Brazil & Region & Brazil \\
State & $\begin{array}{c}\text { County and } \\
\text { region }\end{array}$ & County & $\begin{array}{c}\text { County, region, } \\
\text { state and Brazil }\end{array}$ & County and region \\
\hline
\end{tabular}




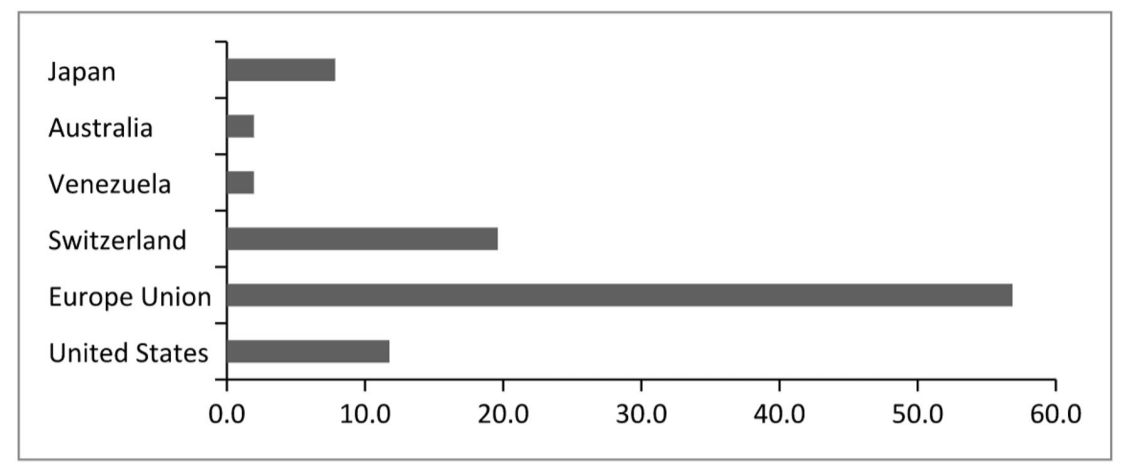

Figure 3. Main importing countries.

\section{Final considerations}

The analysis of commercialization of organic products in Brazil highlights several factors. They include the importance of fresh fruits and vegetables as the major products $(60.6 \%)$; packed products $(43.5 \%)$; the relevance of the states of Rio Grande do Sul, Santa Catarina and São Paulo for the production of organic products.

The commercialization channels may be assessed by certain variables such as the type of presentation of the product, farm size and certification used. It should be observed that commercialization channels range from public and eco-organic fairs to supermarkets, specialized shops, direct selling, PAA and intermediaries. However, supermarkets are the main delivery channels. Supermarkets are among the three most important channels for all types of commercialization of organic products. This fact may be inferred by the large number of these agents in the delivery of organic products in Brazil, already mentioned in the literature.

Products with several types of presentation, mainly washed and processed, are received by the supermarket channels. It should be noted that the greater the transformation or processing degree of the product, the higher is the trend to be forwarded to specific channels, such as specialized shops; otherwise, they go to the public fair. The importance of PAA in the commercialization of semi-processed products should not be underestimated since the commercialization of in natura products is expected in this specific case.

In the case of the size of the farm producing organic products, the small participation of fairs in organic products as compared to public ones should be highlighted. Similarly, there is a great participation of supermarkets and in the commercialization of organic products of small and big producers. The above data show that when small producers decide to commercialize their organic products in public fairs and supermarkets, they receive only a small profit since the prices of organic products in public fairs should be competitive to those of conventional ones. Moreover, supermarkets put pressure on producers for lower prices, who have to lower profits.

In the case of 'type of certification' and 'commercialization channel', third party producers prefer sales with intermediaries, specific shops and supermarkets, whereas SPG-certified producers prefer sales in fairs and PAA. It is very important to remark that SPG producers do not necessarily commercialize their products in groups. It was believed that producers did their certification activities as a team which would lead them to commercialize their products in a team too.

Further, $90 \%$ of commercialization of organic products goes to the internal market and only $10 \%$ for exports (especially to the European Union, particularly Germany). Exports were not high since the sample analyzed only FLV and discarded the category of export products such as soybean and sugarcane.

Current research investigating the commercialization channels of organic products in Brazil demonstrated the importance of this activity and the commercialization not only for small, medium and big farms but also the different types of certification (third party and GPS). The relevance of commercialization channels, such as supermarkets and those of any size, also reveals the importance of collective activities among the smaller producers, aiming at a higher aggregation of the product through delivery in public or specialized fairs, and among the medium and large-sized producers, aiming at a higher aggregation of information and knowledge with a better bargain capacity, inclusively with retail networks and intermediaries.

\section{Acknowledgements}

The authors would like to thank the Conselho Nacional de Desenvolvimento Científico e Tecnológico $(\mathrm{CNPq})$ for funding the research project developed in 2012-2014 and Fundação de Amparo à Pesquisa do Estado de São Paulo (FAPESP). 


\section{References}

Araújo, M. J. (2003). Fundamentos de agronegócios. São Paulo: Atlas.

Associação Brasileira de Supermercados - ABRAS. (2010). Pereciveis. São Paulo: ABRAS. Retrieved in 2010, August 10, from http://www.abrasnet.com.br/ fundacao/index_supermeeting.htm

Barros, G. S. C. (2007). Economia da comercialização agrícola. Piracicaba: Universidade de São Paulo.

Blanc, J. (2009). Family farmers and major retail chains in the Brazilian organic sector: assessing new development pathways. A case study in a peri-urban district of São Paulo. Journal of Rural Studies, 25(3), 322-332. http:// dx.doi.org/10.1016/j.jrurstud.2009.01.002.

Blanc, J., \& Kledal, P. R. (2012). The Brazilian organic food sector: prospects and constraints of faciliting the inclusion of smallholders. Journal of Rural Studies, 28(1), 142-154. http://dx.doi.org/10.1016/j.jrurstud.2011.10.005.

Brasil. (2003, 24 de dezembro). Lei $n^{\circ}$ 10.831, de 23 de dezembro de 2003. Dispõe sobre a agricultura orgânica e dá outras providencias. Brasília, DF: Diário Oficial da República Federativa do Brasil. Retrieved in 2010, August 10, from http://www.planalto.gov.br/ccivil_03/ leis/2003/L10.831.htm

Brasil. (2007, 28 de dezembro). Lei $n^{\circ}$ 6.323, de 27 de dezembro de 2007. Regulamenta a Lei no 10.831, de 23 de dezembro de 2003, que dispõe sobre a agricultura orgânica, e dá outras providências. Brasília, DF: Diário Oficial da República Federativa do Brasil. Retrieved in 2010, August 10, from: http://www.planalto.gov. br/ccivil_03/_ato2007-2010/2007/decreto/d6323.htm

Brasil. Ministério do Desenvolvimento, Indústria e Comércio - MDIC. Secretaria de Comércio Exterior - SECEX. (2010). Exportação de produtos orgânicos: agosto de 2006 a junho de 2010. Brasília: MDIC. Retrieved in 2011, August 10, from http://www.mdic.gov.br

Buainain, A. M., \& Batalha, M. O. (2007). Cadeia produtiva de produtos orgânicos (Série Agronegócios). Brasília: IICA; MAPA/SPA.

Carvalho, Y. M. C. (2005). Construindo a rede paulista de agroecologia. São Paulo: Instituto de Economia Agrícola. Retrieved in 2014, November 10, from http:// www.iea.sp.gov.br/out/LerTexto.php?codTexto=2292

Castro, L. T., Neves, M. F., Consoli, M. A., \& Campos, E. M. (2007). Relacionamento e conflitos em canais de distribuição: um estudo em insumos agrícolas. Revista ADM, 42(2), 167-177.

Companhia Nacional de Abastecimento - CONAB. Programa de Aquisição de Alimentos da Agricultura Familiar. (2006). Renda, cidadania e biodiversidade. Brasília: CONAB. Retrieved in 2013, August 10, from <http:/www. conab.gov.br/conab/Main.php? $\mathrm{MagID}=3 \& \mathrm{MagNo}=41$

Elder, S. D., Lister, J., \& Dauvergne, P. (2014). Big retail and sustainable coffee: a new development studies research agenda. Progress in Development Studies, 14(1), 77-90. http://dx.doi.org/10.1177/1464993413504354.

Fonseca, M. F. A. C., Barbosa, S. C. A., Colnalgo, N. G., \& Silva, G. R. R. (2009). Agricultura orgânica: introdução às normas, regulamentos técnicos critérios para acesso aos mercados dos produtos orgânicos no Brasil. Niterói: Programa Rio Rural. 58 p. Manual técnico.

Forza, C. (2002). Survey research in operations management: a process-based perspective. International Journal of Operations \& Production Management, 22(2), 152194. http://dx.doi.org/10.1108/01443570210414310.

Gil, A. C. (2002). Como elaborar projetos de pesquisa (4th ed.). São Paulo: Atlas.

González, A. A., \& Nigh, R. (2005). Smallholder participation and certification of organic farm products in Mexico. Journal of Rural Studies, 21(4), 449-460. http://dx.doi. org/10.1016/j.jrurstud.2005.08.004.

Guivant, J. S. (2003). Os supermercados na oferta de alimentos orgânicos: apelando ao estilo de vida egotrip. Ambiente e Sociedade, 6(2), 63-81.

International Federation of Organic Agriculture Movements - IFOAM. (2010). The world of agriculture organic: statistics and emerging tendencies. Bonn: IFOAM. Retrieved in 2014, November 10, from http://www. organic-world.net/fileadmin/documents/yearbook/2010/ world-of-organic-agriculture-2010.pdf

International Federation of Organic Agriculture Movements - IFOAM. (2012). The world of agriculture organic. Statistics and emerging tendencies. Bonn: IFOAM. Retrieved in 2014, November 10, from https:/www. fibl.org/fileadmin/documents/shop/1581-organicworld-2012.pdf

International Federation of Organic Agriculture Movements - IFOAM. (2014). The world of agriculture organic. Statistics and emerging tendencies. Bonn: IFOAM. Retrieved in 2014, November 10, from https:/www. fibl.org/fileadmin/documents/shop/1636-organicworld-2014.pdf

Machado, R. T. M. (2000). Rastreabilidade, tecnologia da informação e coordenação de sistemas agroindustriais. (Tese de doutorado). Universidade de São Paulo, São Paulo.

Martins, V. A., Camargo, W. P., Fo., \& Bueno, C. R. F. (2006). Preços de frutas e hortaliças da agricultura orgânica no mercado varejista da cidade de São Paulo. Informações Econômicas, 36(9), 42-52.

Mascarenhas, G., \& Dolzani, M. C. S. (2008). Feira livre: territorialidade popular e cultura na metrópole contemporânea. Ateliê Geográfico, 2(4), 72-87.

Neves, M. F. (1999). Um modelo para planejamento de canais de distribuição do setor de alimentos (Tese de doutorado). Faculdade de Economia, Administração e Contabilidade, Universidade de São Paulo, São Paulo. 
Oliveira, S. L. (2001). Tratado de Metodologia Científica: projetos de pesquisas, TGI, TCC, monografias, dissertações e teses. São Paulo: Pioneira.

Organicos. (2012). Os primeiros números confiáveis da agricultura orgânica no Brasil. Retrieved in 2014, November 10, from http://organicosbrasil.wordpress. com/2012/06/01/os-primeiros-numeros-confiaveis-daagricultura-organica-no-brasil/

Pigatto, G., \& Alcântara, R. L. C. (2006). Relacionamento colaborativo nos canais de distribuição. In L. F. S. Zuin \& T. R. Queiroz. Agronegócios: gestão e inovação. São Paulo: Saraiva.

Rosa, R. C., No., Mendes, A. M., Oliveira, S. J. M., Holanda, Z. F., \& Ribeiro, R. S. (2009). Características do setor de distribuição de mandioca e derivados em Rondônia: um estudo exploratório. In Anais do 47 Congresso Brasileiro de Economia e Sociologia Rural. Porto Alegre: Sociedade Brasileira de Economia, Administração e Sociologia Rural.

Rosenbloom, B. (1999). Marketing channels: a management view. Orlando: The Dryden Press.

Rosenbloom, B. (2002). Canais de marketing: uma visão gerencial. São Paulo: Atlas.

Rossi, A., \& Brunori, G. (2010). Drivers of transformation in the agro-food system: GAS as co-production of alternative food networks. In Proceedings of the 9th European IFSA Symposium. Vienna: Universität für Bodenkultur.
Scalco, A. R., \& Servi, R. G. (2014). Manutenção da certificação orgânica em propriedades rurais. Revista em Agronegócio e Meio Ambiente, 7, 515-534.

Schultz, G. (2006). Relações com o mercado e (re) construção das identidades socioprofissionais na agricultura orgânica (Tese de doutorado). Universidade Federal do Rio Grande do Sul, Porto Alegre.

Silva, C., Perosa, J. M. Y., Rua, P. S., Abreu, C. L. M., Pântano, S. C., Vieira, C. R. Y. I., \& Brizola, R. M. O. (2003). Avaliação econômica das perdas de banana no mercado varejista: um estudo de caso. Revista Brasileira de Fruticultura, 25(2), 229-234. http://dx.doi.org/10.1590/ S0100-29452003000200012.

Souza, M. C. M., Saes, M. S. M., Ramos, S. F., Monteiro, A. V. V. M., Otani, M. N., \& Sampaio, R. M. (2013). ações para o desenvolvimento da agricultura orgânica em São Paulo (Série Estratégias). Rio de Janeiro: Sociedade Nacional de Agricultura, Serviço Brasileiro de Apoio às Micro e Pequenas Empresas, Centro de Inteligência em Orgânicos. 76 p.

Stern, L. W., El-Ansary, A. I., \& Coughlan, A. T. (1996). Marketing channels. Englewood Cliffs: Prentice Hall.

Vorley, B., \& Fox, T. (2014). Global food chains: constraints and opportunities for smallholders. Paris: OECD. Retrieved in 2014, February 25, from http://www1. oecd.org/development/povertyreduction/36562581.pdf

Willer, H., \& Kilcher, L. (2011). The world of organic agriculture: statistics and emerging trends 2011. Bonn: International Federation of Organic Agriculture Movements. 